Article

\title{
The Botica or Apothecary in the Monastery of San Lorenzo el Real de El Escorial (Madrid, Spain): Written Sources, Historic Drawings, and New Surveys Applied to Architectural Analysis
}

\author{
Pilar Chias * and Tomás Abad \\ School of Architecture, University of Alcalá, Alcala de Henares 28801, Spain; tomas.abad@uah.es \\ * Correspondence: pilar.chias@uah.es; Tel.: +34-616-030-335
}

Received: 14 November 2017; Accepted: 22 December 2017; Published: 8 January 2018

\begin{abstract}
Though there are a great number of studies of the Monastery of El Escorial, the surrounding buildings built in the 16th century have gone almost unnoticed. Among them, the Botica or Apothecary was designed by a disciple of Juan de Herrera and still arouses interest for several reasons. Firstly, because it composes an outstanding closure to the Monastery's main building and the surrounding Lonja, while at the same time it connects other neighbouring buildings; secondly, because the surviving documents about its history, uses, and construction processes had not then been studied; and thirdly, because there was no accurate survey permitting an in-depth study of its materials, construction methods, and techniques. We based our research on the information in archive documents, on the study of an outstanding set of ancient drawings, and on the production of a new survey. As a first step, we drew the first set of accurate plans of the building. From this base we undertook the essential formal, functional, and constructive analysis. We also put forward and confirmed the main hypotheses about the building's chronology and the stages of its construction. Finally, we analysed the conservation works that were carried out facing the two main risks of termite attacks and weathering.
\end{abstract}

Keywords: Monastery of El Escorial; Renaissance architecture; historical construction; architectural surveying; scanner laser; 16th century; King Philip II; Spain

\section{Introduction and Precedents}

The Monastery of El Escorial is considered to be one of the most important architectural ensembles of the Renaissance. It was built between 1563 and 1586 following the orders of the King of Spain, Philip II, and due to its singular and monumental character, it was given the name of the "eighth wonder of the world". This tradition, together with the peculiar legends associated with the King's personality, fostered the creation of an extraordinary number of documentary sources by chroniclers, travellers, writers, and researchers. As a result, an extensive amount of literature was produced, showing various approaches to the building, as well as producing an essential corpus of drawings.

It is nevertheless true that most authors focused on the main building of the Monastery, while there are few who have truly appreciated the quality of the surrounding buildings.

We also want to draw attention to the vocabulary used in this work, because it includes some old Castilian words that may be difficult to translate. Aiming to make the text easier to understand, we decided to keep the original words in italics, and to include a Glossary that is sorted alphabetically (see Appendix A). It lists the difficult or specialised words with their definitions, as well as the meaning of the main original proper names of the different quarters of the Monastery. 


\subsection{A Short Description of the Monastery and the Building of the Botica}

The Monastery of El Escorial is located $6 \frac{1}{2}$ miles from Madrid, on the southeastern slope of the Guadarrama Mountains, and it is fairly isolated from the other villages. Due to its strategic location, it dominates the whole surrounding area far beyond the capital of the Kingdom.

The monastic complex was formerly composed of the main building or cuadro, which occupies at ground floor level a rectangle of $580 \times 740$ Castilian feet (about $160 \times 205 \mathrm{~m}$ ); two Casas de Oficios or Houses of Service facing its north façade, which housed some facilities for the Palace; and, finally, a set of buildings known as the Compaña, which accommodated the guest quarters, together with some other crafts that were essential for everyday life in the Monastery such as the bakehouse or tahona, the mill, the smithy, the tannery or curtiduria, and barns, stables and stalls, woodsheds, and warehouses.

The main building is encircled from north to west by a large esplanade or Lonja, which separates the cuadro from the other auxiliary buildings, while from east to south a large platform is occupied by delightful blossoming gardens or jardines pensiles. As they extend all along the platform, they provide a soft transition between the buildings, the orchards, and the woods. On the other hand, the long retaining wall or Muro the los Nichos (Wall of the Niches) supports and raises the platform (Figure 1).

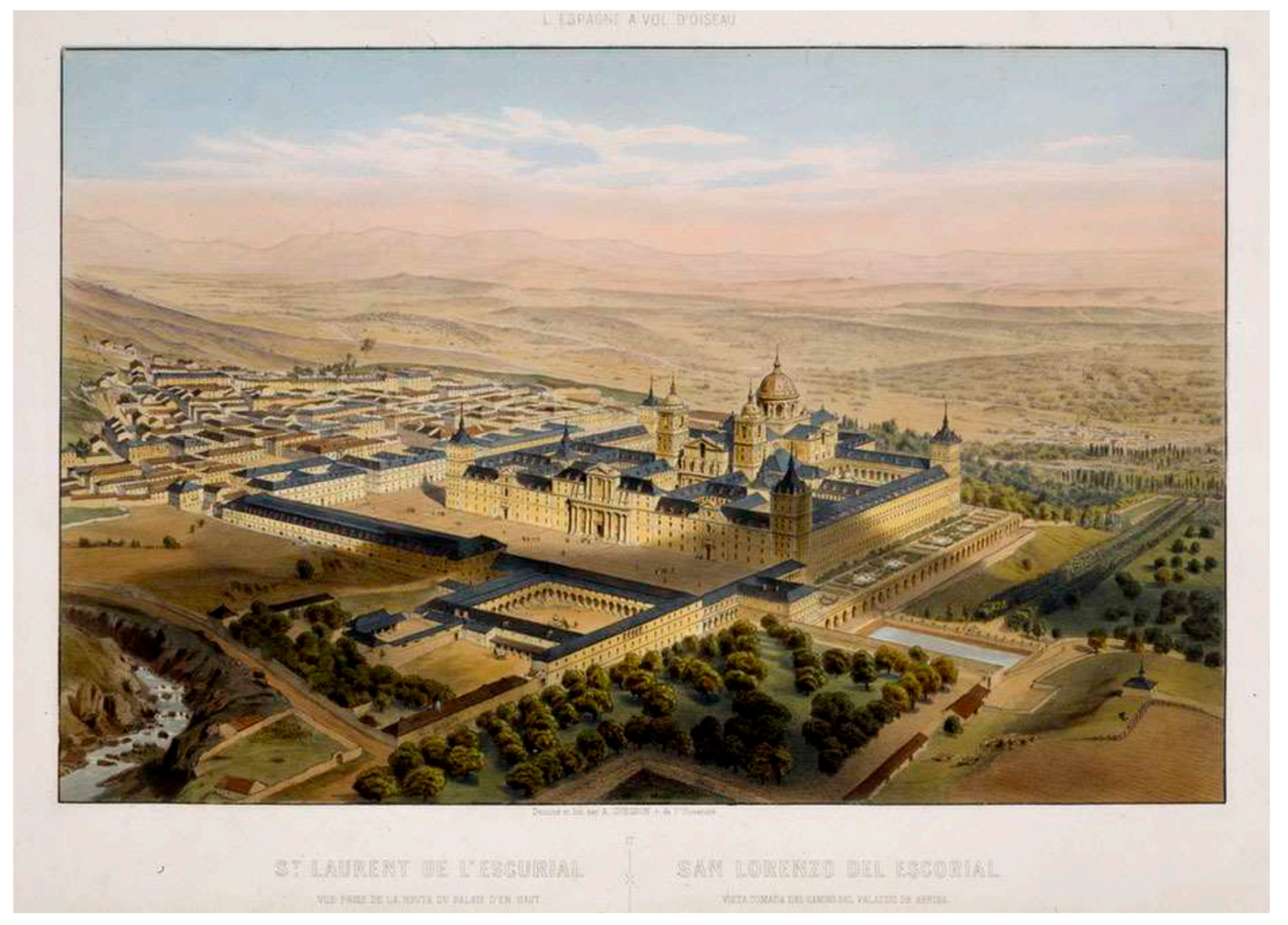

Figure 1. Alfred Guesdon, ca. 1855: L'Espagne à vol d'oiseau. San Lorenzo del Escorial. Vista tomada del camino del Palazzio de arriba. Aerial view of the Monastery from the west. The small square building in front of the main Monastery is the Botica, which is placed next to the Estanque grande (Big Pond) and the Jardin de los Frailes (Garden of the Friars), also is above the long Muro de los Nichos (Wall of the Niches). Biblioteca Nacional de España, Madrid, Bookmark Invent/069192.

The former programme of uses included the burial place of the House of Habsburg (in the crypt beneath the high altar of the huge basilica), a monastery that could accommodate 100 Hieronymite friars, a university college, and a seminary. The cuadro also housed the palace for the members of the royal family and the Court's immediate servants, as well as the Monarch's private apartments or Casa del Rey. 
Organizing the construction of the Monastery was a huge undertaking, due to the rigorous systematic organisation of the works, the quality of the materials, and the solutions applied to the various challenges in construction. As a result, the works were finished in just twenty three years.

The building of the Botica was located outside the main building or cuadro, at the south-western edge of the monastic ensemble. Its rooms were arranged around a cloister with square floor plan, where only two of the four sides were supported by arcades- the north and west cloister galleries or pandas, whilst the east and south sides were almost blind walls-corresponding to the party wall or Galeria de Convalecientes and to the south body of the Botica building. These characteristics will be analysed later.

The Botica is a two storey building, with a vaulted cellar under the south body and an attic. The ground floor level was set at the same height as the platform of the Jardin de los Frailes (Garden of the Friars), while the first floor reached the height of the ground floor of the Monastery, also known as del andar de la casa. As we will see, only the ground floor of the Botica received attention from the world of research, mainly due to its location next to the Gallery of Convalescents.

On the other hand, the Botica is connected with the Monastery through the Gallery, and after the building of the Compaña by means of an exterior arcade. From the point of view of the history of construction, both solutions are particularly interesting.

\subsection{Precedents}

Among the modern contributions that paid attention to the construction of the Monastery throughout the 16th century, the works by Bustamante [1], Kubler [2], Andrés [3], Cervera [4] (pp. 37-64), and Chueca Goitia [5] (pp. 46-53) must be highlighted.

Nevertheless, none of their works dealt with key issues concerning the design of the Monastery's environment such as topography, technical infrastructures, and other facilities such as water supply and drainage, or the construction of the path network. Relationships between all of them and the various service buildings were also traditionally neglected, though they were recently studied by Chías and Abad [6-9].

We aim to fill this gap with the study of the Botica, as it can be considered one of the most interesting and least known buildings of the monastic complex. Its installations served not only the King's need for remedies, but also those of the friars and of the Court.

As detailed in documentary sources, many chroniclers and travellers visited the Monastery from the beginning of the construction until the end of the 19th century, and stressed the importance of the main building. From an architect's perspective, only Íniguez [10], Zuazo [11], and Lorente Junquera [12] showed any interest in the Botica, while their priority was the study of the adjacent Galería de Convalecientes (Figures 2-4).

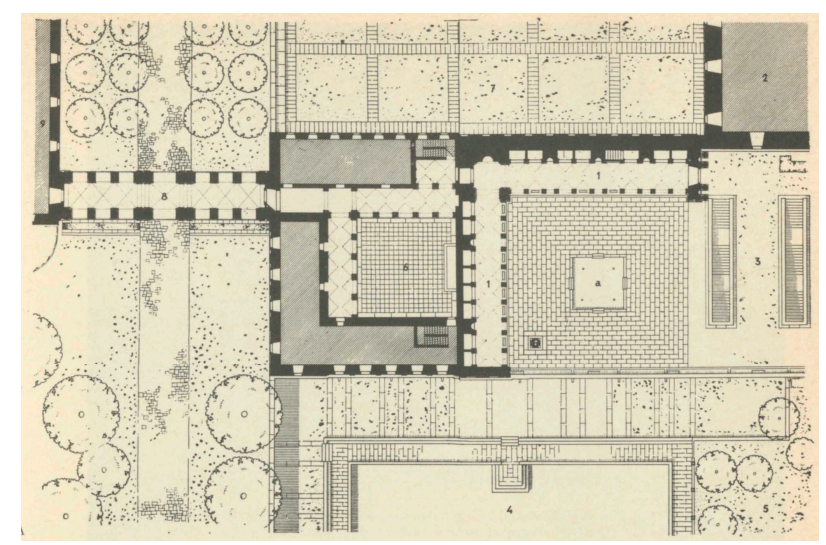

Figure 2. Secundino Zuazo, 1948: ground floor plan at the level of the Jardin de los Frailes, showing the ensemble of the Galería de Convalecientes and the Botica (see reference [11]). 


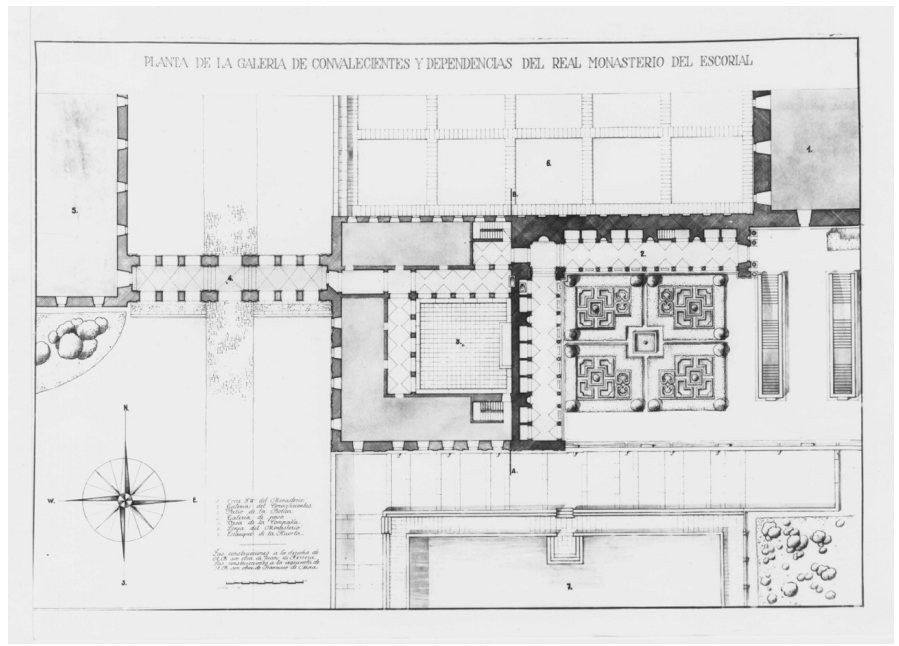

Figure 3. Manuel Lorente, 1944: Planta de la Galería de Convalecientes y dependencias del Real Monasterio del Escorial. Colegio Oficial de Arquitectos de Madrid (Spain), Servicio Histórico, Legado Lorente Junquera, Bookmark MLJ/P01/B3-1-01.

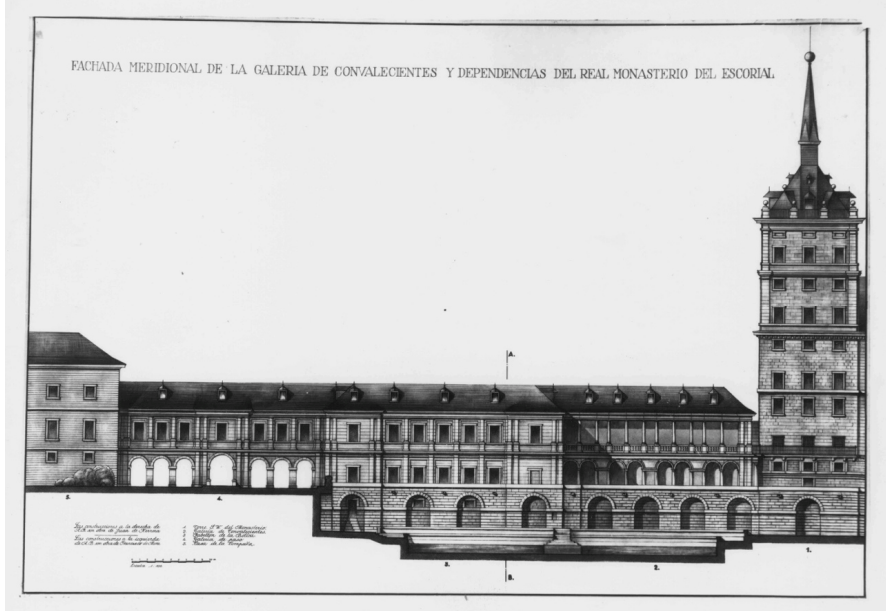

Figure 4. Manuel Lorente, 1944: Fachada principal de la Galería de Convalecientes y dependencias del Real Monasterio del Escorial. Colegio Oficial de Arquitectos de Madrid (Spain), Servicio Histórico, Legado Lorente Junquera, Bookmark MLJ/P01/B3-1-02.

Not only that, but their works consisted of highly simplified small-scale plans of the ground floor at the Friar's Garden level (Figures 1 and 2), which were completed by a south elevation by Lorente (Figure 3). As the figures show, the drawings lack accuracy and both the architectural features and the spatial qualities were poorly defined, not admitting further research.

\section{Alchemy, Medicine, and Illness in the Time of King Philip II and in the Monastery}

In order to get a thorough knowledge of the uses of the Botica in the context of medicine and pharmacy in 16th century Spain, we studied some aspects relating to the history of Science.

From the point of view of alchemy and the study of the products of the monastery's apothecaries, there are important contributions by López Piñero [13], Sánchez Ron [14] (pp. 41-42), and Webster [15] (p. 34). Regarding medicine, iatrochemistry (chemical medicine), botany, and therapeutics in Spain, the works by Puerto [16], Sánchez Ron [14] (pp. 50-56), Barona [17], and Maganto [18] (pp. 13-14, 37-38, 98-103) became essential. 
As King Philip II was fascinated by magic and science, his physicians and their specific drugs and remedies were studied by Parker [19] (pp. 465, 759-762), Oliveros and Subiza [20], Muñoz Calvo [21], and Goodman [22] (pp. 19-24, 263). The King's ailments were frequently mentioned in his private correspondence, which is mainly preserved in the Archivo del Instituto de Valencia de Don Juan and the Archivo Zabálburu, both in Madrid (from now on, IVDJ and AZ respectively), in the British Library, London, Additional Manuscripts (from now on, BL, Add.), and in the set of letters published by Bouza [23].

The works by Alegre [24] about the Royal Apothecaries are also noteworthy.

\section{Diseases, Infirmaries, and Apothecaries in the Monastery}

The main epidemics affecting the area of San Lorenzo at that time were carefully recorded in some documents held in the Archivo Histórico Municipal of El Escorial (from now on, AHME), as well as in the Memorias Sepulcrales [25] of the Monastery. The latter describe the precise causes of death of each one of the friars, the most common being gout or mal de piedra, bubonic plague, spotted fever or tabardillo, cold (or romadizo) and flu, pneumonia (dolor de costado or mal de la muerte), tuberculosis, and other illnesses such as paludism. Accidents were also frequent causes of death.

According to Hossard [26] (pp. 134-135), from the beginning of the construction work the King established health care to treat all the workers' ailments, which may be considered as pioneering in occupational medicine. The five existing infirmaries in the Monastery were guided by the Libro de Costumbres [27] and were supplied by the successive apothecaries that were then present in the monastic complex.

There were two in the area of the convent, extending over the southern part of the Monastery. The first one was located under the Torre del Noroeste (the Northwest Tower), which was built in 1567, adjoining the Claustro Primero or de la Enfermería (First Cloister), also known as Infirmary Cloister, communicating direct with the Galería de Convalecientes (Figure 5).

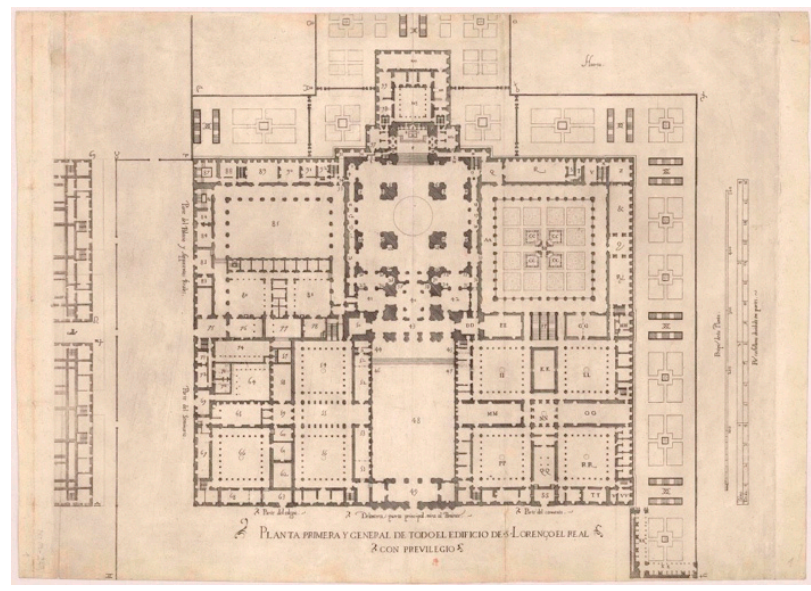

(a)

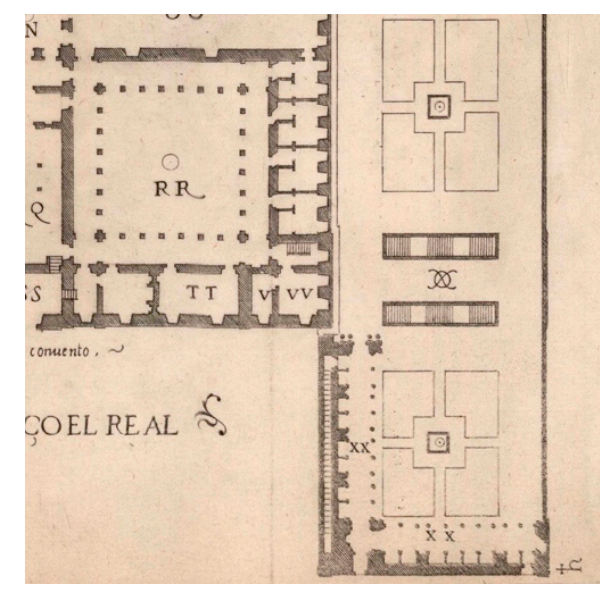

(b)

Figure 5. Juan de Herrera and Pedro Perret, 1587: Primer diseño. Planta general y primera de todo el edificio de S. Lorenço el Real. Architect Juan de Herrera continued and completed the previous architectural project by Juan Bautista de Toledo. He made known the appearance of the Monastery by a set of drawings engraved by Perret. (a) Ground plan of the Monastery, where north is to the left of the picture. (b) Detail of the southwest area where the Claustro de la Enfermería is lettered (RR), the Torre de la Botica (VV), and the Galería de Convalecientes (XX), opened up to the Jardin de los Frailes. The thick wall at the bottom of the figure is the party wall between the Galería and the Botica, while this building was not included because there was no place available on the sheet. The party wall shows gates connecting the two buildings. Biblioteca Nacional de España, Madrid, Bookmark INVENT/28841. 
For the purpose of explaining the content of the engravings, Juan de Herrera published in the year 1589 the Sumario [28] (ff. 12-12v), which is a kind of reading guide [29]. The text accompanying the ground plan in Figure 4 describes the lettering as follows: "V VV. Apothecary and hollow in the tower by this corner, and apart from these rooms it has many useful vaults, and in addition, close to the wall of the corridor of ills by the XX. area, by the west side there is a newly built patio comprising three rooms serving the Botica, where distillations and related activities take place, and over there is a passage from the monastic area to the Compaña, but as it does not fit on the paper, the drawing was not included. / XX. Solarium corridors for convalescents connecting with the new apothecary as mentioned above". Herrera refers here to the adjacent Galería de Convalecientes-also known as Corredorcillos del sol-and the new building for the apothecary or Botica.

This second Botica or Casa para destilar las aguas, which was built outside the cuadro between 1585 and 1592 , is the main subject of our research.

\section{Main Targets}

Main targets and novel contributions are:

1. To survey the Botica and its adjacent buildings, in order to draw a set of accurate up-to-date drawings, plans, elevations, and sections, which did not previously exist.

2. The new survey will put forward and demonstrate some new hypotheses concerning chronology and construction stages of the building complex.

3. To draw up the appropriate formal, functional, and constructive analysis.

4. To analyse the main restorations that were made in order to preserve the building, facing the two main risks of termites and weathering.

\section{Methodology}

The study of the construction of the Botica cannot be separated from studies of the neighbouring Galería de Convalecientes, Muro de los Nichos, and Lonja. This is because the Botica and the Galería are supported by the Muro de los Nichos, a retaining wall that brings a single coherent solution to the height differences between the Lonja and the sidewalk at the foot of the niches -ándito. On the other hand, Botica and Galeria share a party wall, and there is communication by two doors on the lower level, and another two on the first floor.

The attic is currently composed of a single space, though this may be the result of the roof replacement in the 1950s.

The cellars of the Galería and the Botica remain isolated from each other, as they were from the beginning. As we will see, this is due to the different uses they had.

During the construction of the buildings, the measurement unit was the Castilian foot-about $0.2786 \mathrm{~m}$ [30]. For this reason, throughout the surveying process we made accurate measurements by using both systems of units-Castilian foot and meters.

\subsection{Main Written Sources}

Some sources contemporary with the construction of the monastic complex must be stressed. Among them, the original documents and works contracts that are kept in the Real Biblioteca del Monasterio del Escorial (from now on, RBMSLE) and in the Biblioteca and Archivo del Palacio Real de Madrid (from now on, BPR and APR, respectively) are particularly interesting for our purposes. These manuscripts detail carefully the conditions for each task by each labourer, and include measurements, valuations, and payment orders. Furthermore, some of them include original drawings and tracings [31], which can be related to the set of 16th century drawings kept in the BPR and other archives. The study of all this material permitted us to redraw the construction processes and their contexts. 
Another set of essential sources are the manuscript works by contemporary Hieronymite chroniclers such as friar Juan de San Jerónimo [32] (fº 370) and friar José de Sigüenza [33] (pp. 706-854). The work by Philip II's doctor Juan Alonso de Almela [34] (ff. 98v, 183r-188r, 212r-217r) describes carefully the Botica and the Gallery, while the Flemish gentleman Jehan Lhermite [35] (v. II, pp. 71-72) contributes outstanding witness of the daily life at the Spanish court.

With very few exceptions, travellers and visitors to the Monastery as Wadsworth [36] (pp. 11, 14-15) and Fanshawe [37] (p. 157) in the 17th century, and Ponz [38] (v. II, pp. 172, 234-237) in the 18th century praised the gardens but hardly ever paid attention to the Botica or other service buildings. However, those who did so provided valuable information about uses, furniture, botamen (the pharmacy's collection of jars), and state of conservation.

There were few 19th century travellers who visited the Botica, whilst the majority walked through the gardens and the Galería. Travel stories written in the first half of the century portrayed a romantic vision of the Monastery, but new objective perspectives were gradually established, such as those in travel guides. Writers such as Álvarez [39] (p. 220), Ford [40] (v. II, p. 819), Quevedo [41] (p. 348), and Rotondo [42] (pp. 213-214) belong to the first group, while Bermejo [43] (pp. 336-341) and Ramírez y La Guardia [44] (p. 43) are excellent authors of specific guides.

Using these precedents as her basis, Chías [45] puts forward some aspects of the construction of the Botica. As this essay shows, they have been confirmed by means of the survey.

\subsection{Historic Drawings and Sketches. First Hypotheses}

Among the ancient and modern graphic sources dealing with the construction of the Monastery, the twelve engravings or Estampas by Herrera and Perret, drawn between 1583 and 1589, proved useful. The Primer Diseño (first drawing) (see Figure 5), as well as the Sexto and the Séptimo Diseño (sixth and seventh drawings), provide interesting information about the Botica and the Galería. For instance, the Sexto diseño depicts the south elevation while the legend explains: "F.G. Gallery of patients, facing south, and adjacent to it to the west there is a patio with three blocks that serves as the apothecary for distillations and other tasks specific to the profession; it is not represented because there is not enough paper to do so." [28] (fo $25 \mathrm{v}$ ) As a consequence, the drawing is cut off along the party wall between the Galería and the Botica (Figure 6).

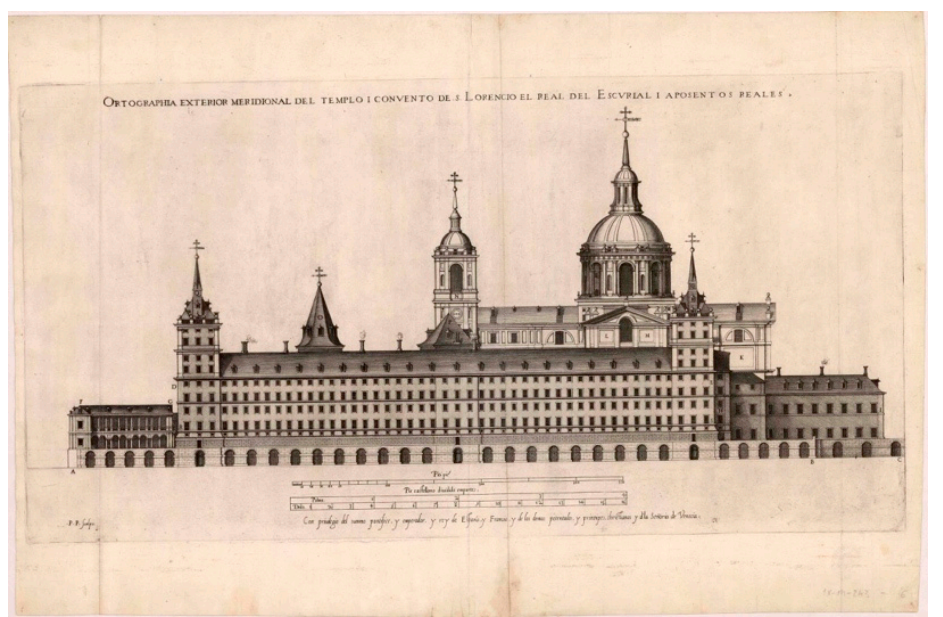

(a)

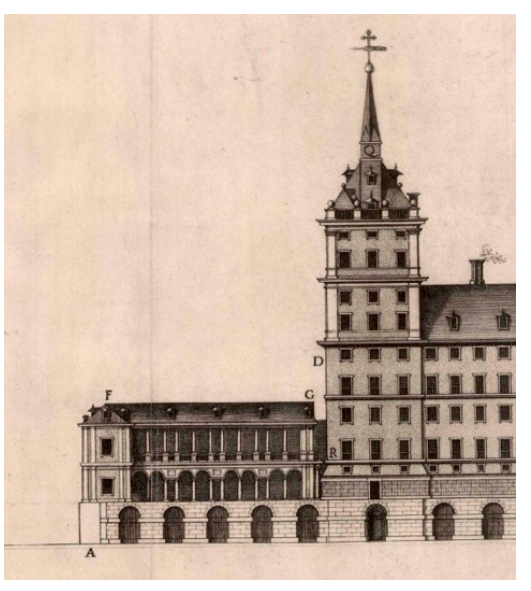

(b)

Figure 6. Juan de Herrera and Pedro Perret, 1587: Sexto diseño. Ortographia exterior meridional del Templo i Convento de S. Lorencio el Real del Escurial i Aposentos Reales. (a) South elevation. (b) Detail of the Galería de Convalecientes or Corredorcillos del Sol, that are located on the left side of the drawing. Biblioteca Nacional de España, Madrid, Bookmark INVENT/28846. 
Detail of Figure $6 \mathrm{~b}$ depicts the Galería lettered ' $\mathrm{F}$ ' and ' $\mathrm{G}$ ' over the ridge. Letter ' $\mathrm{R}$ ' refers to the position of the exterior walkway that links the Torre de la Botica (Tower of the Apothecary or Southwest Tower in the Monastery) to the first floor of the Galería.

Nevertheless, the drawing shows some contradictions if compared with the finished building.

Firstly, the south front of the pitched roof of the Galería is not triangular due to the extension corresponding to the roof of the Botica.

Secondly, the front elevation of the western gallery is not particularly long. At the end all proportions are slightly distorted because the existing parapet of the garden is missing.

Thirdly, the gable under letter ' $G$ ' is not vertical but inclined.

Fourthly, the unroofed external walkway from the Torre de la Botica has proved to be an improvised solution, because the former planned communication between the Monastery and the Galería was through the garden (Figure 7).

Finally, letter 'A' under the section of the Muro de los Nichos on the left side of the drawing defines the height of the sidewalk at the foot of the Wall of the Niches (ándito de la huerta) in relation to the terrain level. However, the wall was finally built beyond this point, about $23.5 \mathrm{~m}$ (84 1/3 Castilian feet) to the west. To explain this, we propose the hypothesis that the construction of the Botica was not planned from the beginning of the work but added at a later stage. As a consequence, the Wall must have been erected at the end of the Galeria and then moved to the west in order to integrate the building into the whole complex, with an open side facing the orchard. In the end, the possibility of building the Botica closer to the Compaña was rejected.

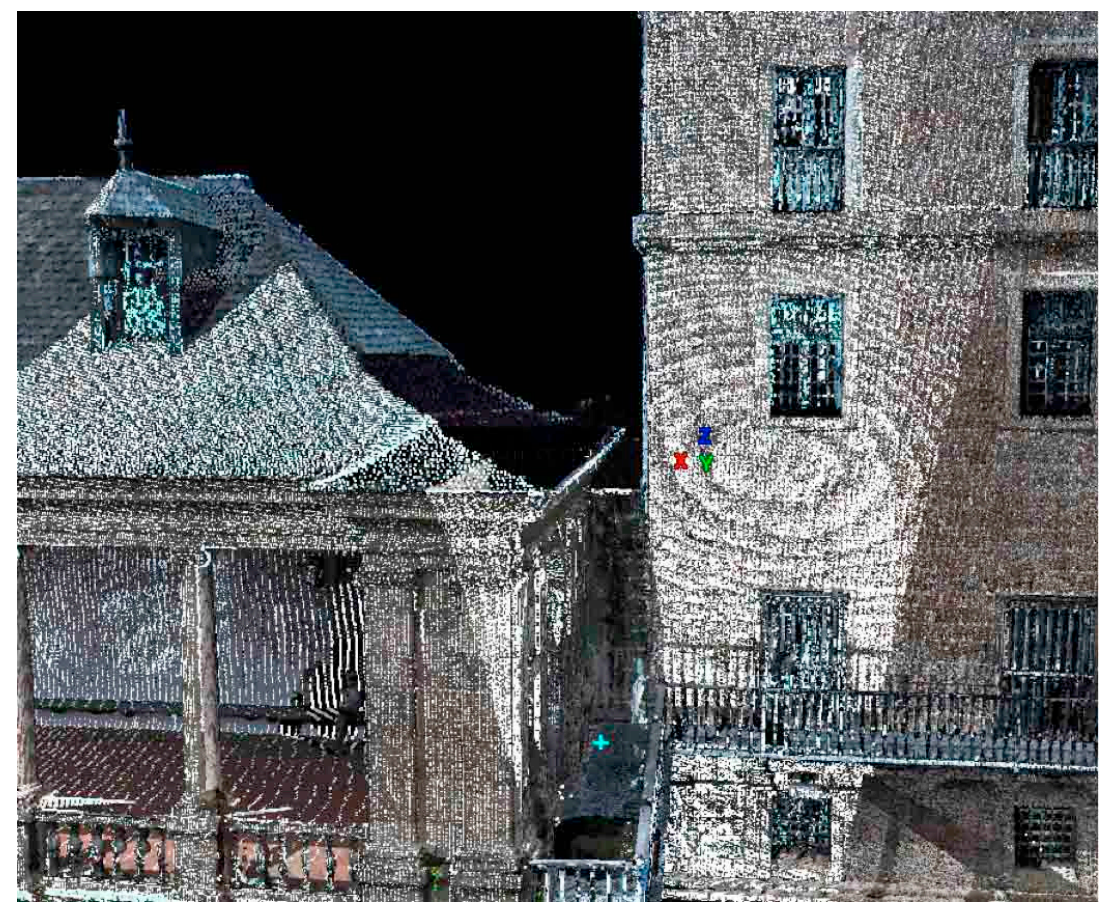

Figure 7. Detail of the point cloud of the pitched roof at the east front of the Galeria de Convalecientes, as registered using Leica Cyclone program. Scan process made by a Leica P40 in RGB and referenced to a local coordinate system.

It is noteworthy that the south façade of the Galería in the Sexto diseño already resembles the final design, being perfectly integrated into the definitive elevation of the Botica.

Similarly, the Séptimo Diseño shows an aerial view of the monastic complex from the west, where the main service buildings can be clearly identified. The Botica is represented on the right side of the engraving, at the foot (Figure 8). 


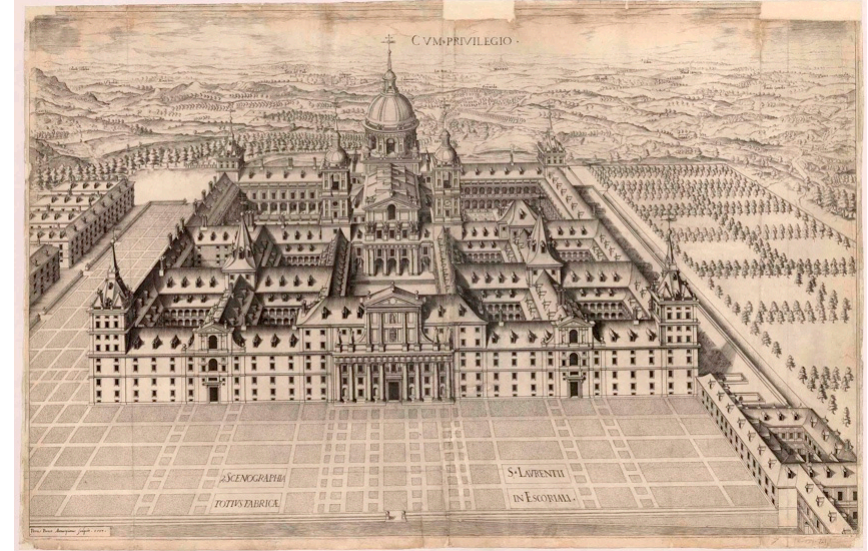

(a)

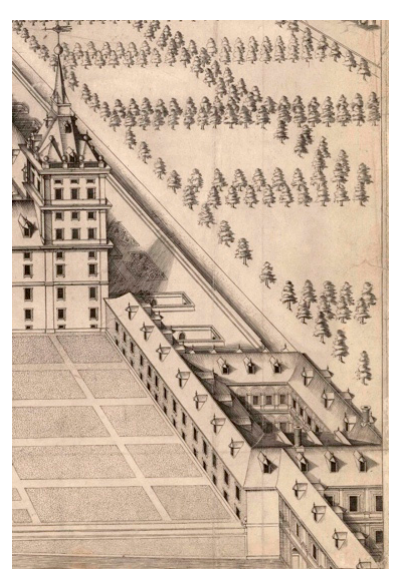

(b)

Figure 8. Juan de Herrera and Pedro Perret, 1587: Séptimo Diseño. Scenographia S. Laurentii Totius Fabricae in Escuriali. (a) Perspective of the Monastery from the west, showing the main entrance and the west Lonja at the foreground. (b) Detail of the Torre de la Enfermería, the gardens, and the building of the Botica surrounding a small patio. The arcade that links the Botica with the Compaña is also depicted. Biblioteca Nacional de España, Madrid, Bookmark INVENT/28857.

Just as when we talked of the Sexto diseño, the differences between the drawing and the finished building are evident. They can be clearly noticed with respect to the pitched roof, but also at the interior east and south walls of the patio, which were built almost entirely blind (Figure 9).

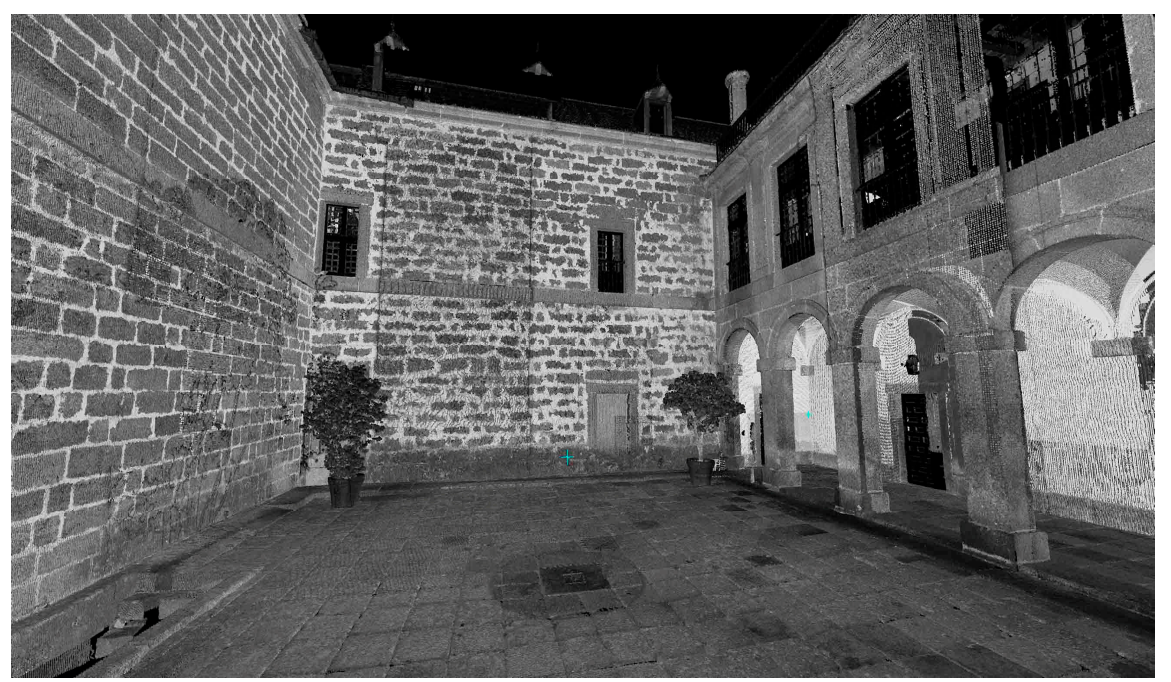

Figure 9. Scanned image in shades of grey of the patio or cloister in the Botica, showing the south wall and the blind east wall on the right side of the image. The arcade corresponds to the west gallery.

For instance, the east wall as shown on the left in Figure 9 is represented in the Séptimo diseño (Figure 8) as a gallery with open lintel openings within a false arcade. The same design is repeated on the south wall. However, a careful examination of Perret's engraving shows that the interior of the windows is lined with an intensity that is different on both walls which does not depend on the incident light.

The hypothesis we propose is that the initial design for the east wall consisted of a series of false windows at both ground floor level and at first floor level, which were to be overlayed to the existing ashlar wall. This solution, simulating a false façade, was frequently applied for compositional reasons to other quarters of the Monastery, but in this case it was never built. 
On the other hand, the south wall was simply unfinished, and only two doors at ground level and two windows on the first floor were built.

Perret's engraving does not show the chimney stacks above the roof either. Smokestacks evacuated the combustion gases and odours produced by the decomposition of plants in the lower cellar of the Galería [46] (Figure 10).

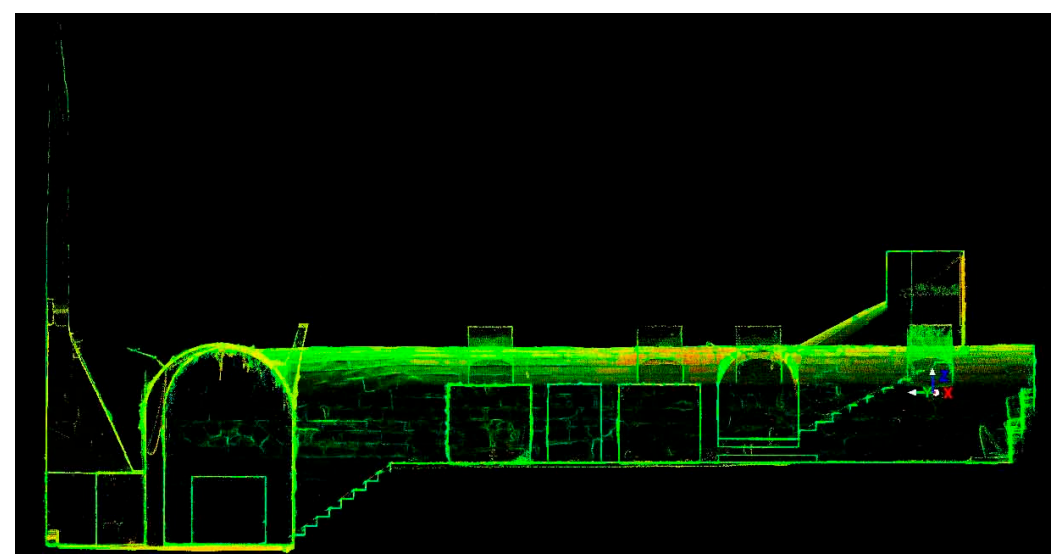

Figure 10. High density point clouds generated from Leica P40 scans. The scanned area corresponds to the upper and lower vaulted cellars of the Galería de Convalecientes. On the left side a smokestack can be seen. The stone staircase that leads to the level of the Jardin de los Frailes is shown on the right side.

It is quite clear that the engravings by Herrera and Perret were produced in accordance with the plans of the Monastery, but not from the finished building. For this reason there is a lack of coherence between them.

There is another interesting 16th century drawing by architect Francisco de Mora, who succeeded Herrera in the supervision of the work of the Monastery. The drawing represents the ground plan of the orchard and the Estanque Grande (the Big Pond), where the Botica, the Galeria, and the platform of the Jardin de los Frailes are shown at the top. Several sections of the Muro de los Nichos close the northern and western sides of the orchard (Figure 11).

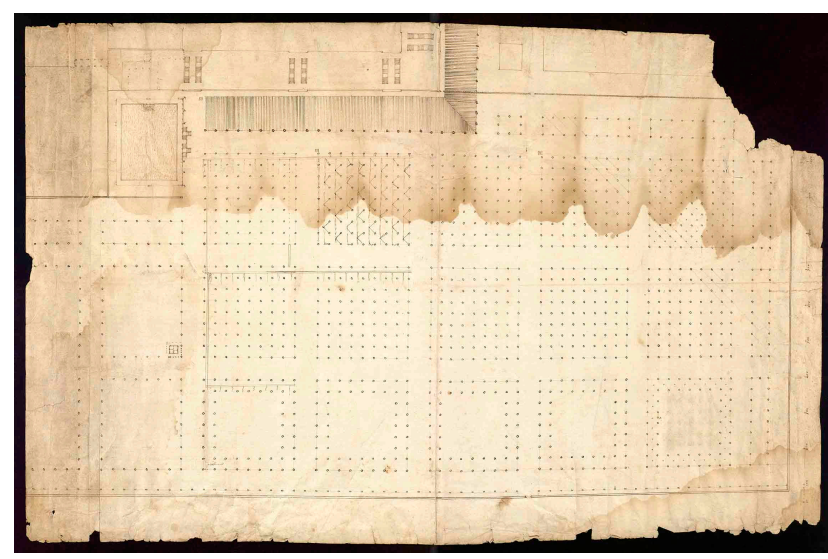

(a)

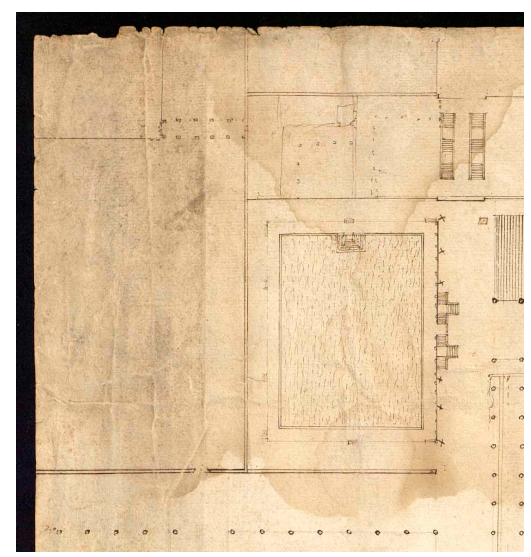

(b)

Figure 11. Francisco de Mora, ca. 1585: Plano de la huerta del Monasterio de San Lorenzo de El Escorial. (a) Ground plan representing the south-western area of the monastic complex, outside the main building of the Monastery. North is at the top of the image. (b) Detail of the upper left side of the drawing showing the Estanque grande, the Galeria de Convalecientes, the new building for the Botica, and the arcade connecting with the Compaña. España, Ministerio de Educación, Cultura y Deporte. Archivo Histórico Nacional, Madrid, M $^{\mathrm{o}}$ de Exteriores, MPD. 157. 
This drawing is particularly interesting because it probably shows the first project for the Botica, when it was still an L-shaped building opening to the south. The two cloister galleries on the north and west sides of the patio are clearly visible as they were built later on. At a second design phase the initial patio was transformed into an enclosed area by constructing the south block. In accordance with the small dimensions of the cloister- $16.21 \times 16.23 \mathrm{~m}$ or $581 / 5 \times 581 / 4$ Castilian feet-the most plausible hypothesis is that it would have been impossible to build two more galleries on the east and south sides of the cloister, as the remaining free space was too small.

Another interesting series of drawings was produced in the mid-eighteenth century. They are useful when comparing the state of the corresponding façades after the alterations introduced by King Charles III.

The series was drawn at the initiative of Count of Aranda, who was the President of the Council of Castile (1766-1773) and Secretary of State (1792) during the reigns of Charles III and Charles IV, respectively. The survey was made under the direction of José de Hermosilla and developed by engineers Bécaud y Fillera in 1759 [47,48] (Figures 12 and 13).

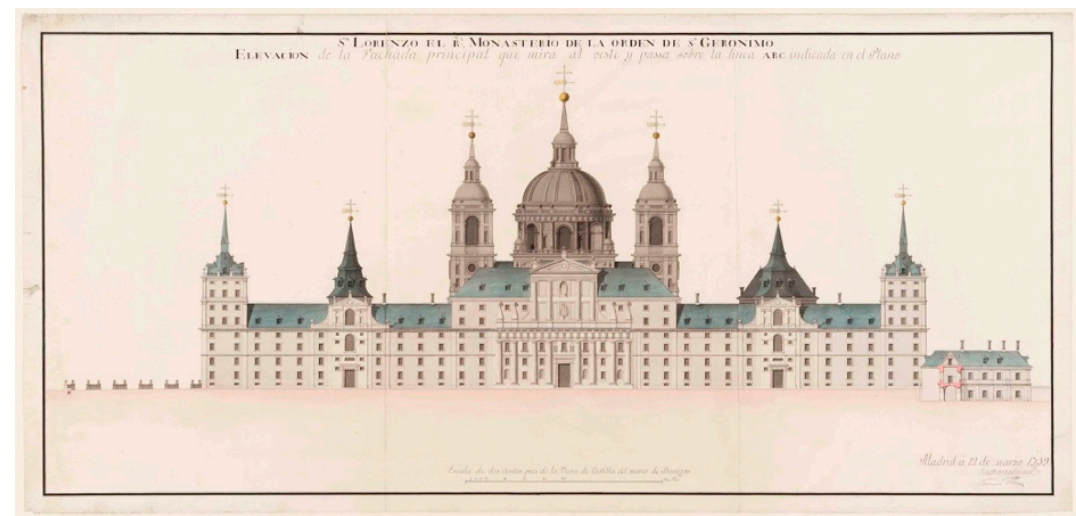

(a)

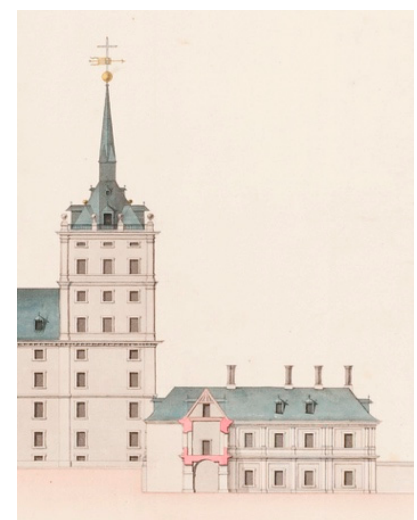

(b)

Figure 12. Bernardo Fillera and Balthazar Bécaud, 1759: San Lorenzo el $R^{l}$ Monasterio de la orden de $S^{n}$ Geronimo. Elevacion de la Fachada principal que mira al oeste y passa sobre al linea ABC indicada en el Plano. (a) West elevation or main façade. (b) Detail of the western elevation of the Botica with a cross section of the arcade that connects with the Compaña. Canadian Centre for Architecture, Montréal, DR1986:0722.

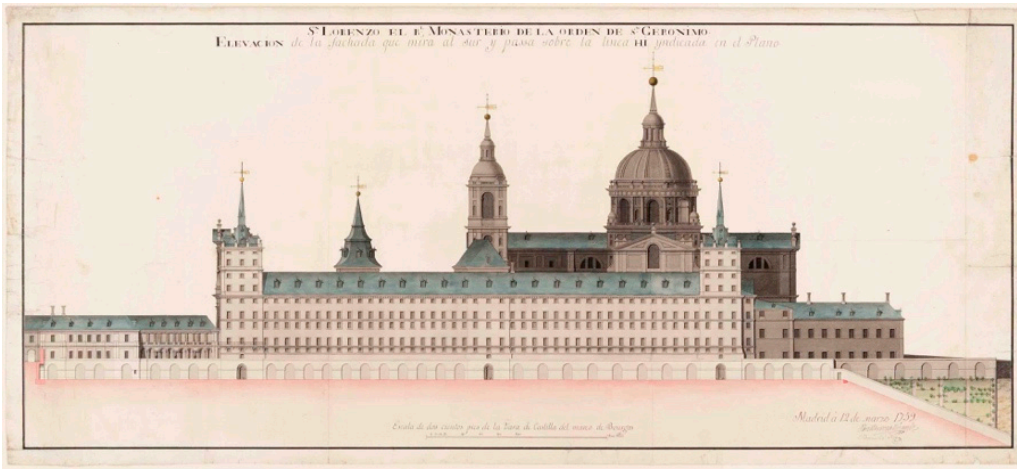

(a)

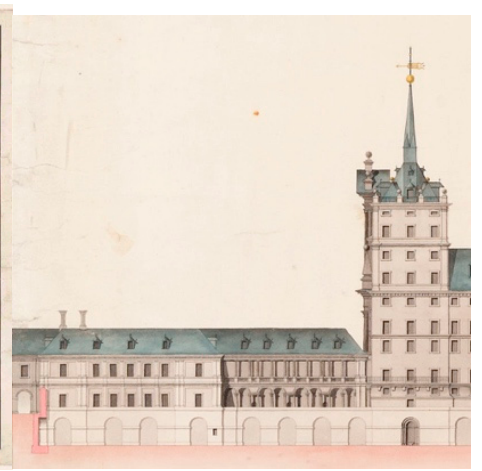

(b)

Figure 13. Bernardo Fillera and Balthazar Bécaud, 1759: San Lorenzo el $R^{l}$ Monasterio de la orden de $S^{n}$ Geronimo. Elevacion de la Fachada que mira al sur y passa sobre la linea HI yndicada en el Plano. (a) South elevation of the Monastery. (b) Detail of the façades of the Botica and the Galería de Convalecientes facing to the orchard. Canadian Centre for Architecture, Montréal, DR1986:0725. 
It is also interesting to compare the 18th century drawings and the 16th century engravings by Herrera and Perret (see Figure 6), because the former represent the Botica as it should have been done in accordance with the original draft.

\subsection{Surveying Methods}

The surveys of the buildings of the Galeria, the Botica, and Muro de los Nichos were carried out between 2015 and 2017.

In the first phase we focused on the study of the most relevant spaces and architectural features such as vaults, stairs, etc., which we measured directly using a laser measurement device and measuring tape. This stage permitted us to plan the work in accordance with the layout of the complex and the topography, as well as to assess the strategies to be followed when using the high definition laser scanner, a Leica Scanstation P40 (Leica Geosystems, Heerbrugg, Switzerland), that offers a distance measurement range of $120 \mathrm{~m}$ at $8 \%$ reflectivity that fits perfectly with the conditions of the complex of buildings.

At this point we detected some problems which had to be solved throughout the scanning process.

Firstly, because of the great quantity of furniture and other objects stored in the rooms, and particularly in the attic and offices, it proved necessary to clean the point cloud before any manipulation or export to CAD (AutoCad 2018, Autodesk, San Rafael, CA, USA) programs.

Secondly, in order to get an overall view of the complex and to confirm the hypothesis about the uses and connectivities established between buildings, we concluded that the cellar of the Galería should be integrated in the surveying campaigns (see Figure 10).

Thirdly, there is an important difference in height and a lack of visibility between some station points, a problem that is solved by inserting a set of intermediate station points in order to identify some common reference points that are visible from several station points. In this case, the need to close the polygon, whose vertices are the station points, led us to define a set of architectural elements visible from the main door of the monastery at the Lonja level-and one of the station points at the level of the Jardin de los Frailes-EST-021:SW-021 (Figure 14). The common points to be seen from both stations were located at the ridge over the Galeria and at the mouldings of the east gable and the Torre de la Enfermería (see Figure 7).

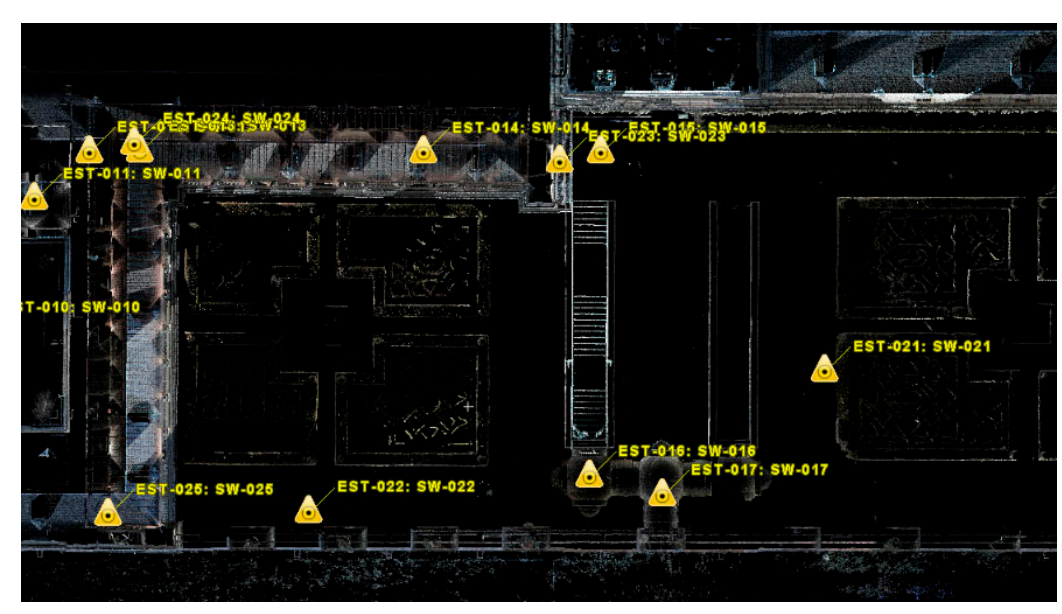

Figure 14. Station points located in the Botica and the Galeria (both of them are at the height of the Jardin de los Frailes (EST-010:SW-010 to EST-015:SW-015)), points on the Jardin (EST-021:SW-021 and EST-022:SW-022), and another at the level of the ground floor of the Monastery (EST-023:SW-023 to EST-025:SW-025). Station points defined with numbers lower than EST-010:SW-010, correspond to locations outside the complex to the north and west sides, while those between EST-016:SW-016 and EST-020:SW-020 correspond to positions at the height of the sidewalk at the foot of the Muro de los Nichos. 
After considering all of these aspects, we decided to undertake the survey of all the neighbouring constructions such as the Galería, Muro de los Nichos, and the arcade to the Compaña, as they constitute an indissoluble whole (Figure 15).

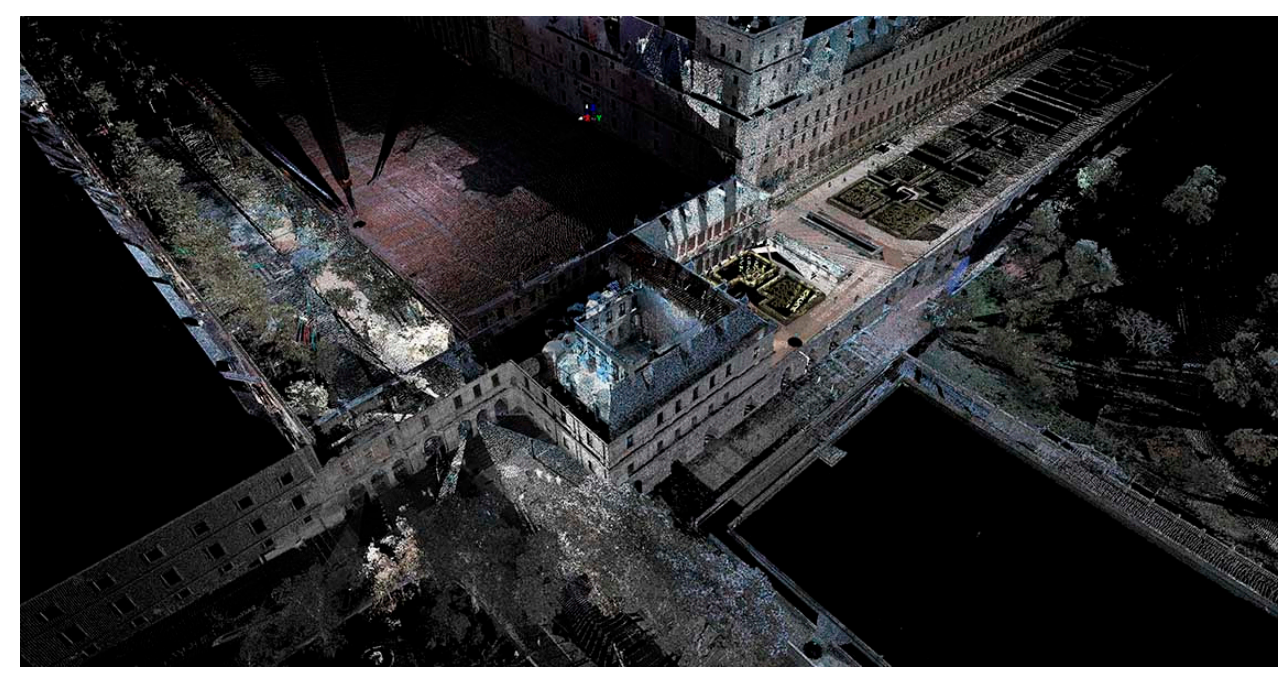

Figure 15. Aerial view of the generated 3D textured model of the area surrounding the Botica, after processing by the Leica Cyclone software (Cyclone 9.2, Leica Geosystems, Heerbrugg, Switzerland).

In parallel, we dealt with the study of the chronology of the construction of the area and its principal former uses.

As a first stage of the surveying process, considering that the highest elements in the Monastery to be surveyed are about 90 feet high, we used a Leica Scanstation P40 with its range of distances (up to $60 \mathrm{~m}$ ), and defined a set of 24 station points.

As a second stage, for surveying rooms, cellars, attics, and inner architectural elements we used a portable BLK360 Imaging Laser Scanner (Leica Geosystems, Heerbrugg, Switzerland) with a distance range of $40 \mathrm{~m}$, sharing some station points with the previous surveying stage, being 36 in total. Both 3D laser scanners have integral internal cameras, and point clouds can be managed by the same Cyclone software.

Once the surveying campaigns were finished, we processed the data sets in order to analyse bondings and construction techniques. We also exported them to AutoCad with the purpose of drawing accurate plans, sections, and elevations (Figures 16 and 17).

Throughout the drawing process we must stress that measurements that were previously obtained by using direct techniques and a laser measurement device proved to be as accurate as those provided by the scanner laser. Nevertheless, it permitted us to get some data related to inaccessible architectural elements such as mouldings, ridges, and dormers or gables, and it was useful for defining shapes and ornaments.

We are currently drawing some building details and ornaments on a larger scale, as well as the singular architectural elements such as stairs, columns and capitals, wells, and fountains (Figures 18 and 19). 


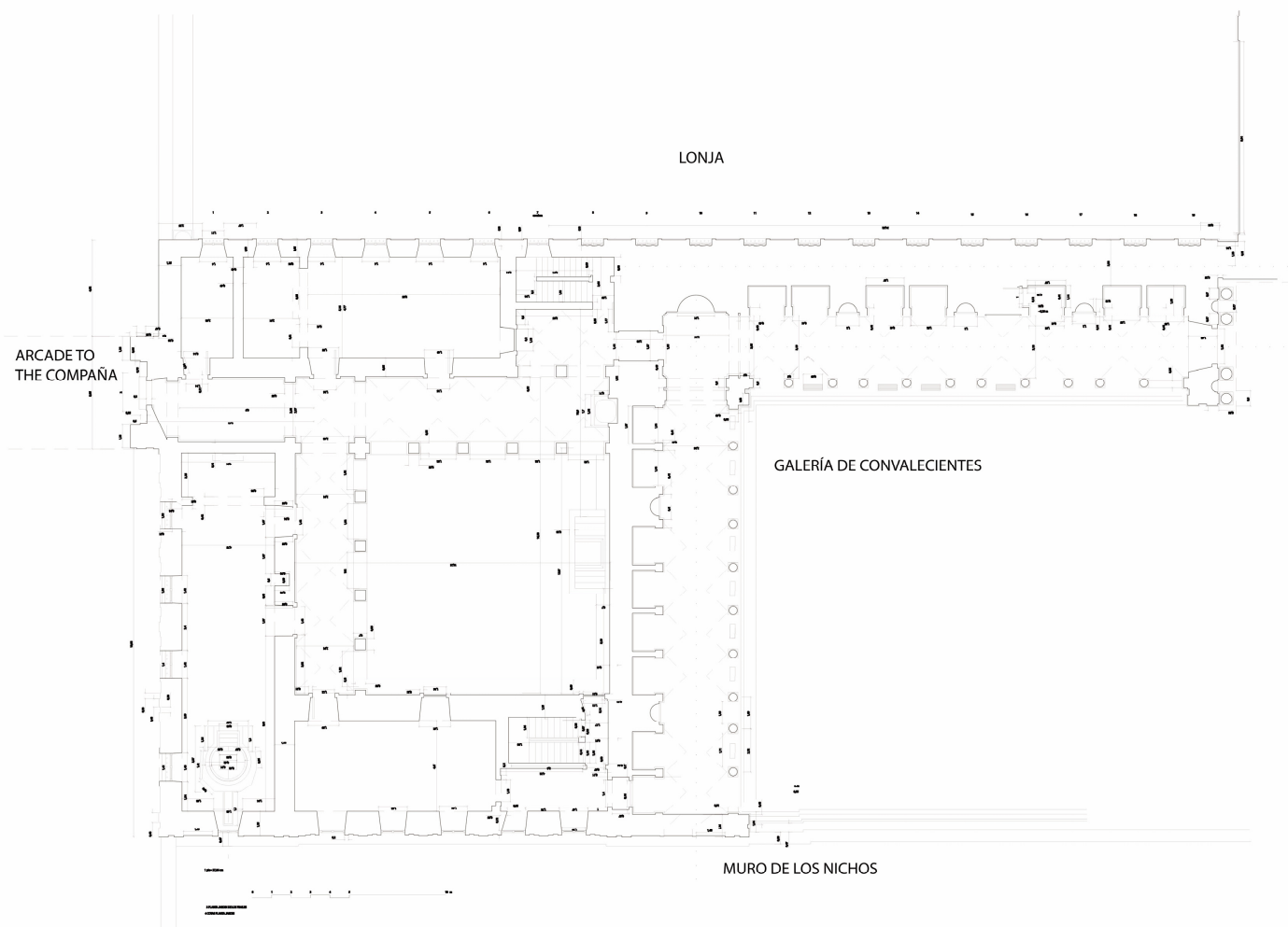

Figure 16. Pilar Chías and Tomás Abad, 2017: Ground plan of the complex of the Botica and Galería de Convalecientes at the level of the Jardin de los Frailes. Original scale 1:50.

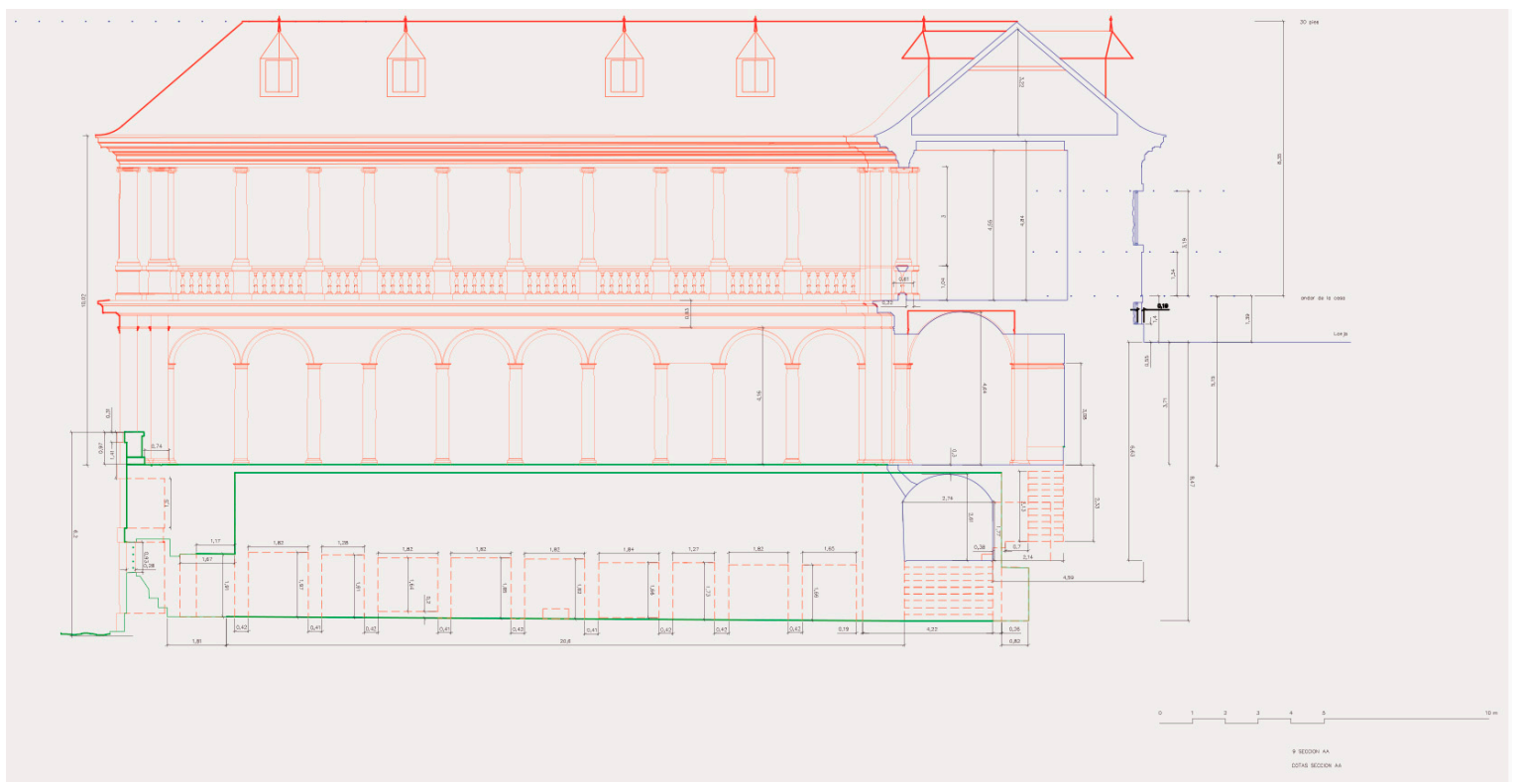

Figure 17. Pilar Chías and Tomás Abad, 2017: Section drawing of the complex of the Botica and Galería de Convalecientes. Original scale 1:50. Blue lines correspond to the cross section showing the upper cellar of the Galería, while green lines depict the longitudinal section of the lower cellar. 


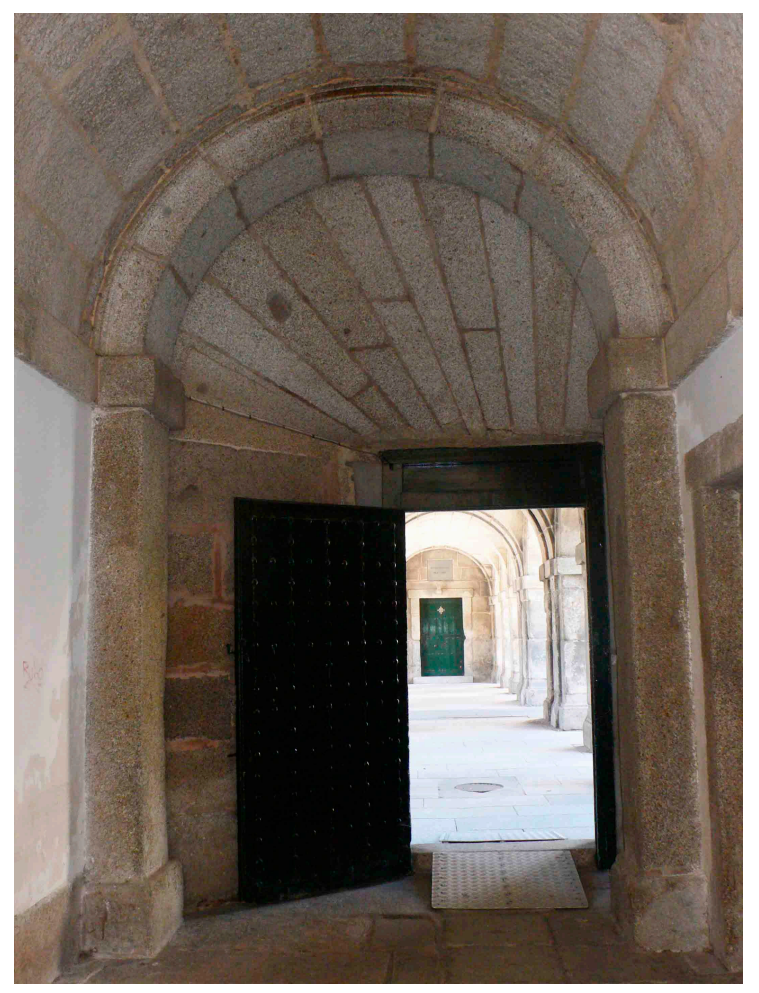

Figure 18. Arcade to the Compaña as seen from the Botica. The stereotomy of the vault must be stressed. Photograph by the authors.

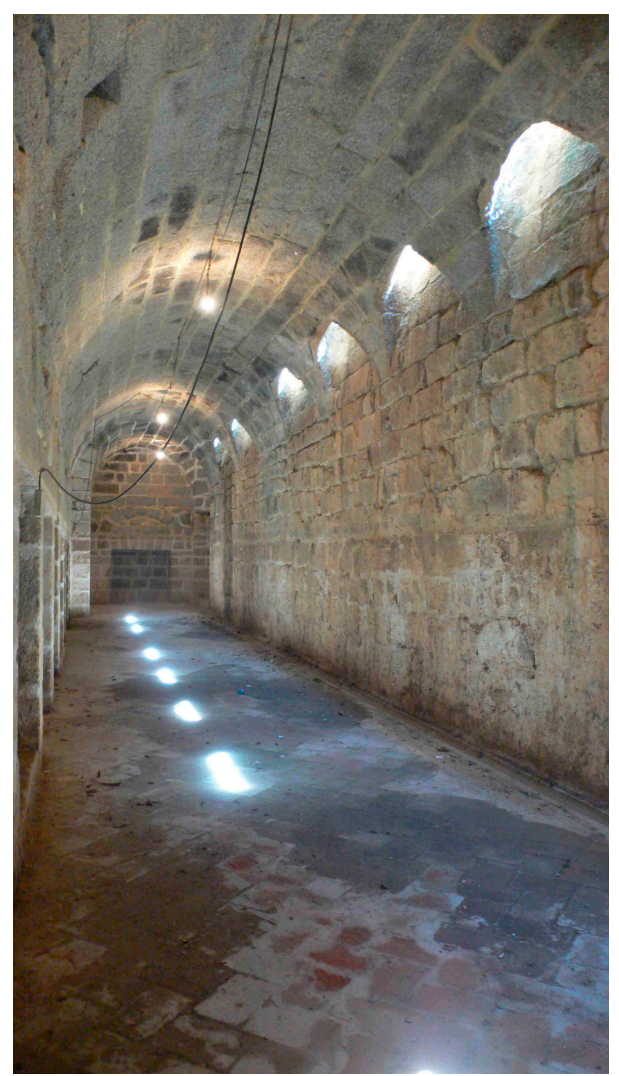

Figure 19. The lower cellar of the Galería from the south. Photograph by the authors. 


\section{Discussion}

On the one hand, the research based upon the accurate survey permitted us to detect some interesting variations in quality of the building materials, as well as some peculiar solutions and construction techniques. The retaining wall of the Lonja and the various vaulted cellars are outstanding examples.

On the other hand, the new set of drawings, together with the datasets related to the construction of the complex of buildings that were found in the various archives, allowed us to propose a definite chronology of the successive stages of construction.

The main pathologies of the complex have been also detected, while the infrared camera integrated in the BLK360 Imaging Laser Scanner has proved to be a very useful tool to study the humidities and their effects. The full-colour panoramic images overlaid on the high-accuracy point cloud evidenced the impact of recent restorations.

Finally, documents and other written and literary sources revealed for the first time some interesting information about the uses and tasks within the building, and the relationships established with the neighbouring buildings. As a result, the Botica and the Galeria "returned to life" just as it had been throughout the 16th and 17th centuries.

All these aspects are discussed below.

\subsection{Chronology of a Construction}

Aiming to clarify some questions related to the construction phases of the complex of buildings, we provided an exhaustive study of the documentary sources related to the work contracts. As a result, we fixed the contract and construction date for each part of the buildings and for each of the tasks involved.

According to this set of data we produced a timetable explaining the successive stages of the construction of the complex of buildings comprising the Galería, Botica, the garden, the Muro de los Nichos, and the arcade to the Compaña.

- The excavation works and foundations of the south sections of the Muro de los Nichos were undertaken between 1563 and 1564. However, the platform supporting the gardens and the stairs descending to the orchard were finished only in 1571, while the fountain basins were installed in 1572 .

- The levelling of the western Lonja, together with the sewage and the construction of the retaining wall of the Botica, were undertaken between the fall of 1564 and springtime of 1565 . The retaining wall included some buttresses, because it had to support the section of the Galería facing south.

- This first section of the Galería was designed at the end of 1564. From the beginning, it was provided with a vaulted cellar, a gallery at garden level, and another at the height of the ground floor of the Monastery. In fact, this one communicated with the Torre de la Enfermería by means of an outdoor cantilevered walkway. This stage of the construction work started in 1565 and was finished in May 1567.

- In 1574, seven years after ending the first section of the Galería, a new perpendicular section was proposed in order to enclose the garden from the west side. The new section was built with the same structure and order, but a new vaulted cellar was also added. The stonework of this section was completed by mid-1578, and the carpentry finished at the end of the year.

- The conditions that were necessary to build the new building for the Botica o Casa para destilar las aguas behind the second section of the Galeria were defined in 1585 . The construction work continued until 1590, when the crane was taken away. Although conditions required that the new building should be built with the same formal characteristics of the neighbouring Galería, due to the urgent need for their use the new facilities were built almost entirely without decoration in a plain and strictly functional manner. On the other hand, the work affected once again the terrains of the western Lonja, which needed to be contained, as well as the water supply and the Muro 
de los Nichos, which had to be extended to the west in the year 1586. At first, the Botica was to be L-shaped and open to the south, but the lack of space and the impossibility of extending to the west meant that the patio was soon closed by a third block. In 1590 the whole building was fully operational.

- Finally, in 1586, the new arcade was designed to connect the Botica and the Compaña, and it was finished in 1587.

\subsection{Main Risks: Pathologies and Recent Restorations}

There were two main risks affecting the integrity of the building.

The first risk was the weathering of granite due to the temperature differences suffered by the exterior walls of the Galería. The scarce ashlars and pieces affected were replaced by new ones with similar carving. However, they are easy to identify. Some other pieces show superficial effects, but stability was never damaged.

The second risk is the action of xylophage insects, as termites had nested inside the box hedges in the garden and had attacked the wooden roof structures in the Botica and Galería. The solution adopted at the end of the 1960s was the substitution of the whole wooden structure by a metal framework with infills of brick and concrete decks [49]. The problem was solved while the formal image of the buildings was preserved, but the old wooden roof structures were lost.

\subsection{Reconstruction of the Original Uses of the Building in Their Context}

The study in depth of the building in relation to other adjacent constructions permitted us to reconstruct the old uses as explained by contemporary witnesses such as Doctor Almela [34] (Book III, cap. XXV, ff. 186-187) and the Flemish gentleman Jehan Lhermite [35] (t. II, pp. 71-72). They described the five offices in the ground floor that held some distilleries and ovens, while the upper floor contained the "gran máquina de Matiolo" (Matiolo's big machine), distilleries of quintaesencias (quintessences), and the famous and enormous torre filosofal.

However, they say nothing about the uses of the wide and well-ventilated vaulted cellars used to classify the various plant varieties that grew in the adjacent medicinal garden and the orchard. They also served to clean, cut, and dry out, and to submit to further processes of composting and separation that sometimes produced unpleasant odours. For this reason, the chimney stacks are built on the west side of the ridges, in an attempt to keep them away from the main building of the Monastery and the quiet pleasant Corredorcillos del Sol.

Authors scarcely ever refer to the interior vertical connections- to two interesting stone stairways, one of them not connected to the attics, and to the other which connects with the cellars-nor to the horizontal connections, which can be summed up in the cantilevered corridor leading to the Monastery, and the arcade to the Compaña.

These peculiar solutions are explained by particular uses, as also are the interruptions and connections with other parts of the Monastery and the garden and the orchard.

\section{Conclusions}

A high-accuracy survey, together with the study of documentary sources (both graphic and written) and the testimonies of witnesses to the building process of the Monastery, permit us to draw up the timetable of the successive stages of construction and the functioning of this part of the Monastery throughout the 16th and 17th centuries.

Likewise, surveys show the true dimensions of the architectural elements, what makes it possible to assess the scope and importance of every one of the construction stages and the effects on the adjacent buildings such as the successive extensions of the Muro de los Nichos and the west Lonja.

In the near future we will continue with the surveys and the study of other service buildings of the Monastery that still lack accurate and reliable plans, such as the three Houses of Service (Casas de 
Oficios), the Compaña, Princes' and Queen's Houses (Casas de Infantes y de la Reina), the House for the orchard keeper (Cachicania), and the ice house (Pozo de la Nieve).

At a later stage we will survey the two 18th century casinos or pleasure villas also known as the Casita del Principe and the Casita del Infante.

Finally, we intend to survey the interior rooms and spaces of the main building of the Monastery that have not been studied yet.

Acknowledgments: We wish to thank Patrimonio Nacional de España and the Augustinian Community of the Monastery for the facilities they gave us in order to develop this research.

Author Contributions: Both authors are responsible of the whole article and participated equally in the research process. The only individual contributions are that Cad drawings are by Pilar Chias, and the Glossary is by Tomás Abad.

Conflicts of Interest: The authors declare no conflict of interest.

\section{Appendix A. Glossary}

- Ándito, the sidewalk at the foot of the Wall of the Niches.

- Botamen, the pharmacy's collection of jars.

- Botica, the apothecary.

- Cachicanía, the house for the orchard keeper.

- Casa de Oficios, House of Service.

- Casa del Rey, the King's private apartments.

- Casa para destilar las aguas, the House to distil essences.

- Casas de Infantes y de la Reina, Princes' and Queen's Houses.

- Casino, a small pleasure villa.

- Claustro de la Enfermería, the Infirmary cloister.

- Compaña, a group of buildings that houses some of the services of the Monastery such as warehouses, mill and stables.

- Corredorcillos del sol, the solarium corridors.

- Cuadro, the main building of the Monastery.

- Curtiduría, a tannery.

- Estanque grande, the Big Pond.

- Faja, a strip.

- Galería de Convalecientes, the Gallery of Convalescents.

- Iatroquímica, Iatrochemistry or chemical medicine.

- Jardin de los Frailes, the Garden of the Friars.

- Jardín pensil, a delightful blossoming garden, orchard.

- Libro de Costumbres, the Customary of the Monastery.

- Limatesa, the ridge.

- Lonja, the yard that extends along the northern and southern façades of the Monastery.

- Memorias Sepulcrales, Sepulchral Memorials.

- Muro de los Nichos, the Wall of the Niches.

- Panda, a cloister gallery.

- Pie castellano, old Castilian foot.

- Pozo de Nieve, ice house.

- Quintaesencia, the quintessence.

- Séptimo diseño, the 7th Drawing.

- Sexto diseño, the 6th Drawing.

- Sumario, Summary. 
- Tahona, a bakehouse.

- $\quad$ Torre de la Botica, the Tower of the Apothecary.

- Torre filosofal, a steam oven or distillation chamber with multiple stills.

\section{References and Notes}

1. Bustamante, A. La Octava Maravilla del Mundo (Estudio Histórico Sobre El Escorial de Felipe II); Editorial Alpuerto: Madrid, Spain, 1994; ISBN 8438102301.

2. Kubler, G. Building the Escorial; Princeton University Press: Princeton, NJ, USA, 1982; ISBN 0691039755.

3. Andrés, G. Inventario de Documentos sobre la Construcción y Ornato del Monasterio del Escorial Existentes en el Archivo de su Real Biblioteca, (Anejo de Archivo Español de Arte); CSIC: Madrid, Spain, 1958; ISSN 0004-0428.

4. Cervera, L. Conjuntos y caminos en torno al Monasterio de San Lorenzo el Real. In Población y Monasterio-El Entorno, IV Centenario del Monasterio de El Escorial; Ministerio de Obras Públicas: Madrid, Spain, 1986; pp. 37-64, ISBN 84-505-3894-7.

5. Chueca, F. El proceso proyectivo del Monasterio del Escorial. Arquitectura 1981, 231, 46-53.

6. Chías, P. The Royal Country Estates around the Monastery of El Escorial: Medieval tradition and Flemish influence/Fincas y cazaderos reales en el entorno del Monasterio de San Lorenzo de El Escorial: Tradición medieval e influencia flamenca. Rev. EGA 2014, 46-53. [CrossRef]

7. Chías, P.; Abad, T. Terrestrial and Aerial Ground-penetrating Radar in use for the Architectural Researches: Ancient 16th Century Water Supply and Drainage at the Monastery of El Escorial (Madrid, Spain). Int. Arch. Photogramm. Remote Sens. Spat. Inf. Sci. 2013, XL-5/W2, 177-182.

8. Chías, P.; Abad, T. Building the surroundings of the Monastery of San Lorenzo de El Escorial: Water, territory and landscape/La construcción del entorno del Monasterio de San Lorenzo de El Escorial. Agua, territorio y paisaje. Informes de la Construcción 2014, 66, 1-12. [CrossRef]

9. Chías, P.; Abad, T. The transformation of topography and landscape in the construction of the Monastery of El Escorial/La transformación de la topografía y del paisaje en la construcción del Monasterio de El Escorial. Informes de la Construcción 2016, 68, 1-12; ISSN-E 1988-3234. [CrossRef]

10. Íñiguez, J.L. Las Trazas del Monasterio de San Lorenzo de El Escorial; (Discurso de ingreso); Real Academia de Bellas Artes de San Fernando: Madrid, Spain, 1965.

11. Zuazo, S. Los Orígenes Arquitectónicos del Real Monasterio de San Lorenzo de El Escorial; Real Academia de Bellas Artes de San Fernando: Madrid, Spain, 1948.

12. Lorente, M. La Galería de Convalecientes, obra de Juan de Herrera. Archivo Español de Arte 1944, 17, $137-147$.

13. López Piñero, J.M. Ciencia y Técnica en la Sociedad Española de los Siglos XVI-XVII; Labor Universitaria: Barcelona, Spain, 1979; ISBN 978-84-335-1723-4.

14. Sánchez Ron, J.M. Felipe II, El Escorial y la ciencia europea del siglo XVI. In La Ciencia en el Monasterio del Escorial; Campos y Fernández de Sevilla, F.J., Ed.; Real Centro Universitario Escorial-María Cristina: San Lorenzo del Escorial, Spain, 1993; Volume 1, pp. 39-72, ISBN 84-86161-36-3.

15. Webster, C. De Paracelso a Newton. La Magia en la Creación de la Ciencia Moderna; Fondo de Cultura Económica: Mexico City, Mexico, 1988; ISBN 978-607-16-4482-4.

16. Puerto, F.J. La Farmacia renacentista española y la botica de El Escorial. In La Ciencia en el Monasterio del Escorial; Campos y Fernández de Sevilla, F.J., Ed.; Real Centro Universitario Escorial-María Cristina: San Lorenzo del Escorial, Spain, 1993; Volume 1, pp. 73-132, ISBN 84-86161-36-3.

17. Barona, J.L. El Escorial y las nuevas corrientes de la medicina renacentista. In La Ciencia en el Monasterio del Escorial; Campos y Fernández de Sevilla, F.J., Ed.; Real Centro Universitario Escorial-María Cristina: San Lorenzo del Escorial, Spain, 1993; Volume 1, pp. 155-188, ISBN 84-86161-36-3.

18. Maganto, E. La Enfermería Jerónima del Monasterio del Escorial: Su Historia y Vicisitudes Durante el Reinado de Felipe II; Real Centro Universitario Escorial-María Cristina: San Lorenzo del Escorial, Spain, 1995; ISBN 84-86161-42-8.

19. Parker, G. Felipe II, la Biografía Definitiva; Ed. Planeta: Barcelona, Spain, 2010; ISBN 978-840-80-9484-5.

20. Oliveros, M.T.; Subiza, E. Felipe II. Estudio Médico-Histórico; Ed. Aguilar: Madrid, Spain, 1956.

21. Muñoz Calvo, S. El medicamento en la medicina de cámara de Felipe II. In La Ciencia en el Monasterio del Escorial; Campos y Fernández de Sevilla, F.J., Ed.; Real Centro Universitario Escorial-María Cristina: San Lorenzo del Escorial, Spain, 1993; Volume 1, pp. 243-274, ISBN 84-86161-36-3. 
22. Goodman, D. Poder y Penuria. Gobierno, Tecnología y Ciencia en la España de Felipe II; Alianza Editorial: Madrid, Spain, 1990; ISBN 978-842-06-2636-9.

23. Bouza, F.J. (Ed.) Cartas de Felipe II a Sus Hijas; Ed. Akal: Madrid, Spain, 1998; ISBN 978-84-460-0991-7.

24. Alegre, M.E. La Real Botica. In La Ciencia en el Monasterio del Escorial; Campos y Fernández de Sevilla, F.J., Ed.; Real Centro Universitario Escorial-María Cristina: San Lorenzo del Escorial, Spain, 1993; Volume 1, pp. 133-154. ISBN 84-86161-36-3.

25. Memorias Sepulcrales. Archivo del Palacio Real, Madrid, Ms. San Lorenzo, leg. 1791.

26. Hossard, J. La Pharmacie de l'Escorial: Ce qu'elle fut-Ce qui reste. Revue d'histoire de la Pharmacie 1961, 170, 134-139. [CrossRef]

27. Libro que Contiene las Costumbres y Oficios que se Guardan y Practican en el Noviciado del Real Monasterio de San Lorenzo; Biblioteca del Monasterio del Escorial: Madrid, Spain, 1800.

28. De Herrera, J. Sumario y breve declaración de los diseños y estampas de la Fábrica de S. Lorenzo el Real del Escorial, 1589. Biblioteca Nacional de España, Madrid, Bookmark Secc. Raros, R/35254.

29. Cervera, L. Las Estampas y el Sumario de El Escorial por Juan de Herrera; Editorial Tecnos: Madrid, Spain, 1954; DL: M-46.455-1998.

30. Real Orden de 9 de Diciembre de 1852, Por la Que se Determinan las Tablas de Correspondencia Recíproca entre las Pesas y Medidas Métricas y las Actualmente en uso. Available online: http:/ /www.cem.es/sites/ default/files/00000458recurso.pdf (accessed on 10 November 2017).

31. Chías, P.; Abad, T. Scale models, templates, drawings, and full-scale tracings in the construction of the Monastery of San Lorenzo del Escorial/Modelos, plantillas, trazas y monteas en los contratos para la construcción del Monasterio de San Lorenzo de El Escorial. Informes de la Construcción 2017, 69, e219, ISSN-E 1988-3234. [CrossRef]

32. De San Jerónimo, J. Libro de Memorias Deste Monasterio de San Lorenzo El Real [1591]; Real Biblioteca del Monasterio de San Lorenzo del Escorial, Bookmark Ms. K-1-7.

33. De Sigüenza, J. La Fundación del Monasterio de El Escorial, (Tercera Parte de la Historia de la Orden de San Gerónimo); Real Biblioteca del Monasterio de San Lorenzo del Escorial, Bookmark Ms. \&-II-22.

34. Almela, J.A. Descripción de la Octava maravilla de el Mundo que es la excellente y Sancta casa de sant Laurencio, el Real Monasterio de frailes hieronimos y Collegio de los mesmos y seminario de letras humanas y sepultura de Reyes y Casa de recogimiento y descanso después de los trabajos de el Gobierno. Fabricada por el muy alto y poderoso Rey y Señor nro. Don Phillippe de Austria segundo de este nombre. Compuesto por el Doctor Juan Alonso de Almela medico. Natural y vezino de Murcia dirigido a la real Magd de el Rey Don Phillippe, 1594; Bookmark Ms.; Biblioteca Nacional de España: Madrid, Spain, 1724.

35. Lhermite, J. Bibliothèque royale de Belgique, Bruxelles, Manuscripti historici $\mathrm{n}^{\circ}$ 17. In Le Passetemps; 2 vols; Ruelens, C., Ouverleaux, E., Petit, J., Eds.; Cited by the 1890-1896 edition; Antwerpsche Bibliophilen: Gent, 'S Gravenhage, Belgique, 1602.

36. Wadsworth, J. The Present Estate of Spain or A True Relation of Some Remarkable Things Touching the Court, and Government of Spayne; Imprinted at London by A.M. for Ambrose Rutherdon, at his Shop at the signe of the Bull head in Pauls Church, 1630.

37. Fanshawe, A. Memoirs of Lay Fanshawe wife of the Right Hon. Sir Richard Fanshawe, Bart. Ambassador from Charles the Second to the Court of Madrid in 1665; S. and R. Bentley: London, UK, 1829.

38. Ponz, A. Viage de España, o Cartas, en que se da Noticia de las Cosas mas Apreciables, y Dignas de Saberse que hay en ella su Autor Pedro Antonio de la Puente. Segunda edición, con estampas. Madrid. MDCCLXXVII. Por D. Joachin Ibarra, Impresor de Cámara de S.M. Se hallará en la librería de Esparza, Puerta del Sol, 1777.

39. Álvarez, F. Descripción del Monasterio y Palacio de San Lorenzo, Casa del Príncipe, y demás notable que encierra bajo el aspecto histórico, literario y artístico el Real Sitio del Escorial, para uso de los viageros y curiosos que lo visiten; Imprenta de Vicente Lalama: Madrid, Spain, 1843.

40. Ford, R. A Handbook for Travellers in Spain and Readers at Home; John Murray: London, UK, 1845.

41. De Quevedo, J. Historia del Real Monasterio de San Lorenzo, llamado comúnmente del Escorial, Desde su Origen y Fundación Hasta fin del año 1848. Y Descripción de las Bellezas Artísticas y Literarias que Contiene; Establecimiento Tipográfico de Mellado: Madrid, Spain, 1849.

42. Rotondo, A. Historia Descriptiva, Artística y Pintoresca del Real Monasterio de San Lorenzo, Vulgarmente Llamado del Escorial; por D. Eusebio Aguado, Impresor de Cámara de S.M. y de su Real Casa: Madrid, Spain, 1863. 
43. Bermejo, D. Descripción Artística del Real Monasterio de S. Lorenzo del Escorial y sus Preciosidades Después de la Invasión de los Franceses; Imprenta de Doña Rosa Sanz: Madrid, Spain, 1820.

44. Ramírez y La Guardia, L. Visita a la Octava Maravilla del Mundo. Guía del Viajero en San Lorenzo del Escorial. Descripción con curiosísimos y minuciosos datos; Imprenta a cargo de Gregorio Juste: Madrid, Spain, 1874.

45. Chías, P. La Botica del Monasterio de San Lorenzo el Real de El Escorial. Una visión desde la arquitectura. In De la Botica de El Escorial a la Industria Farmacéutica: En torno al Medicamento; Gomis, A., Rodríguez Nozal, R., Eds.; Publicaciones de la Universidad de Alcalá: Alcalá de Henares, Madrid, Spain, 2015; pp. 23-66, ISBN 978-84-16133-77-2.

46. Chías, P.; Abad, T.; Echeverría, E.; Miguel, M.; Llorente, P. Underground surveying: 16th century cellar vaults in the Galería de Convalecientes, Monastery of San Lorenzo del Escorial. Int. Arch. Photogramm. Remote Sens. Spat. Inf. Syst. 2017, XLII-2/W3. eISSNN 2194-9034. [CrossRef]

47. Marías, F. El Escorial entre dos Academias: Juicios y dibujos. Reales Sitios 2001, 38, 2-19.

48. Chías, P. Two centuries of iconographic revitalisation of the Monastery of El Escorial, 1600-1800/Dos siglos de revitalización en la iconografía del Monasterio de El Escorial, 1600-1800. Rev. EGA 2017, 28-37, e-ISSN 2254-6103. [CrossRef]

49. Andrada, R. Total renovación de las cubiertas del Monasterio del Escorial. Reales Sitios 1969, 8, 73-76.

(C) 2018 by the authors. Licensee MDPI, Basel, Switzerland. This article is an open access article distributed under the terms and conditions of the Creative Commons Attribution (CC BY) license (http://creativecommons.org/licenses/by/4.0/). 